\title{
AMBOPHILY IN THE DIOECIOUS WEEDY MANGROVE ASSOCIATE, EXCOECARIA AGALLOCHA (EUPHORBIACEAE)
}

Henry Jonathan KARAMSETTY * and Jacob Solomon Raju ALURI *

* Andhra University, Department of Environmental Sciences, Visakhapatnam, China Waltair Street, India, IN-530 003, khjonathan@gmail.com,solomonraju@gmail.com

DOI: 10.2478/trser-2018-0009

KEYWORDS: Dioecy, ambophily, mangrove associate.

ABSTRACT

Excoecaria agallocha is a deciduous tree species dispersed as mangrove associate in oligohaline to polyhaline areas of the mangrove forest. The existence of male and female tree ratio is $2: 1$. The ratio of male to female flowers is $16: 1$. It is an constrained out-crosser and is pollinated by insects like bees, flies, butterflies, and wind, which constitute ambophily. Anemophily make certain the realization of sexual reproduction if the insect pollinators are nor present and such a breeding system is a "fail-safe" strategy for reproductive assurance during colonization. Natural fruit set rate is $92 \%$. Fruit predation by Chrysocoris partricius is $25 \%$; it consumes the fruits prior to their fall from the mother plant. This tree species occupies the cleared or open areas within the mangrove forest and acts as an invasive mangrove associate.

RÉSUMÉ: L’Ambophilie chez l'espèce rudérale décidue associée aux mangroves Excoecaria agallocha (Euphorbiaceae).

Excoecaria agallocha est une espèce d'arbre associée aux zones oligohalines jusqu'aux zones polyhalines des forêts des mangroves. C'est une espèce décidue avec un taux d'occurrence d'arbre mâle-arbre femelle de 2:1. Le rapport des fleurs mâles et des fleurs femelles est de 16:1. L'espèce se reproduit par pollinisation croisée systématique, étant pollinisée par des insectes comme les abeilles, mouches et papillons mais aussi par le vent, ce qui la rend ambophile. L'anémophilie assure le succès reproducteur dans l'absence des insectes pollinisateurs, un tel système reproductif étant une stratégie "sûre à 100\%" assurant la reproduction durant l'étape de colonisation. Le taux de fructification est de $92 \%$. La prédation des fruits par Chrysocoris partricius est de 25\%; le dernier consomme les fruits avant que celles-ci tombent de la plante mère. Cet espèce d'arbre occupe les zones ouvertes et défrichées de la forêt des mangroves et se comporte en tant qu'associé invasif des mangroves.

REZUMAT: Ambofilie la specia ruderală deciduă asociată mangrovetumurilor, Excoecaria agallocha (Euphorbiaceae).

Excoecaria agallocha este o specie de arbore întâlnită în asociații din zonele oligohaline până la polihaline ale pădurilor de mangrove. Este o specie deciduă, cu un raport de prezență arbore mascul la arbore femel de 2:1. Raportul de flori mascule la femele este de 16:1. Specia necesită obligatoriu polenizare încrucişată, realizată prin intermediul insectelor, precum albine, muște și fluturi, care, împreună cu vântul, conferă caracterul ambofil al speciei. Anemofilia asigură succesul reproducerii sexuate în absența insectelor polenizatoare, un astfel de sistem reproducător furnizând o strategie „sigură 100\%” în timpul colonizării de noi spații. Rata naturală de fructificare este de $92 \%$. Prădătorismul fructelor de către Chrysocoris partricius este de $25 \%$; specia consuma fructele înainte de desprinderea lor de planta mamă. Această specie de arbore ocupă zonele deschise sau defrișate din pădurile de mangrove și acționează ca un asociat invaziv al mangrovelor. 


\section{INTRODUCTION}

Mangroves forests are important for coast protection, biodiversity conservation, livelihood opportunities and supply of fishery and fuel and furniture wood resources (Spalding, 1997; Field, 1998; Alang et al., 2010; Azis and Hashim, 2011).

The genus Excoecaria, with 35 to 40 species, belongs to Euphorbiaceae family. The species are distributed from tropical Africa and Asia to the Western Pacific. The important characters of the genus include dioecy, axillary inflorescences, three-stamened male flowers, and caruncle-free seed. Three species, E. agallocha, E. dallachyana and E. indica (Figs. 1a-c), are found in mangroves. But only E. agallocha is widely known as a constituent of mangrove cover. It is distributed from East Africa, India, and Ceylon to Hainan and the Ryu-Kyu Islands through Malesia and Papuasia, including tropical Australia and into the Pacific as far as Niue and Samoa (Tomlinson, 1986). It is an evergreen mangrove tree which usually borders mangrove swamps towards land and appears to be bee-pollinated (Tomlinson, 1986). Sexual reproduction in this species is reported to be restricted due to dioecious sexual system, malebiased sex ratio, and poor seed set and germination rate (Rao et al., 1998).

In India, it occurs in all mangrove locations on the east and west coast. Outside India, its leaf and stem sap is used to treat epilepsy, conjunctivitis, dermatitis, leprosy and tooth ache (Bandaranayake, 1998). The sap of plant parts is used as arrowhead poison to kill fish (Miles et al., 1998). In Bangladesh, the wood is used for making matchsticks, light weight boxes and also as raw material for newsprint and other paper production (Das and Siddiqui, 1985). In the study area, the leaves are used as fodder for livestock to obtain more quantity of milk. The wood is also used as firewood. In cleared or degraded pockets in the study area, it is found to invade quickly and establish its populations. Since there is no detailed information on the reproductive aspects of this mangrove associate, the present study seeks to provide the same.

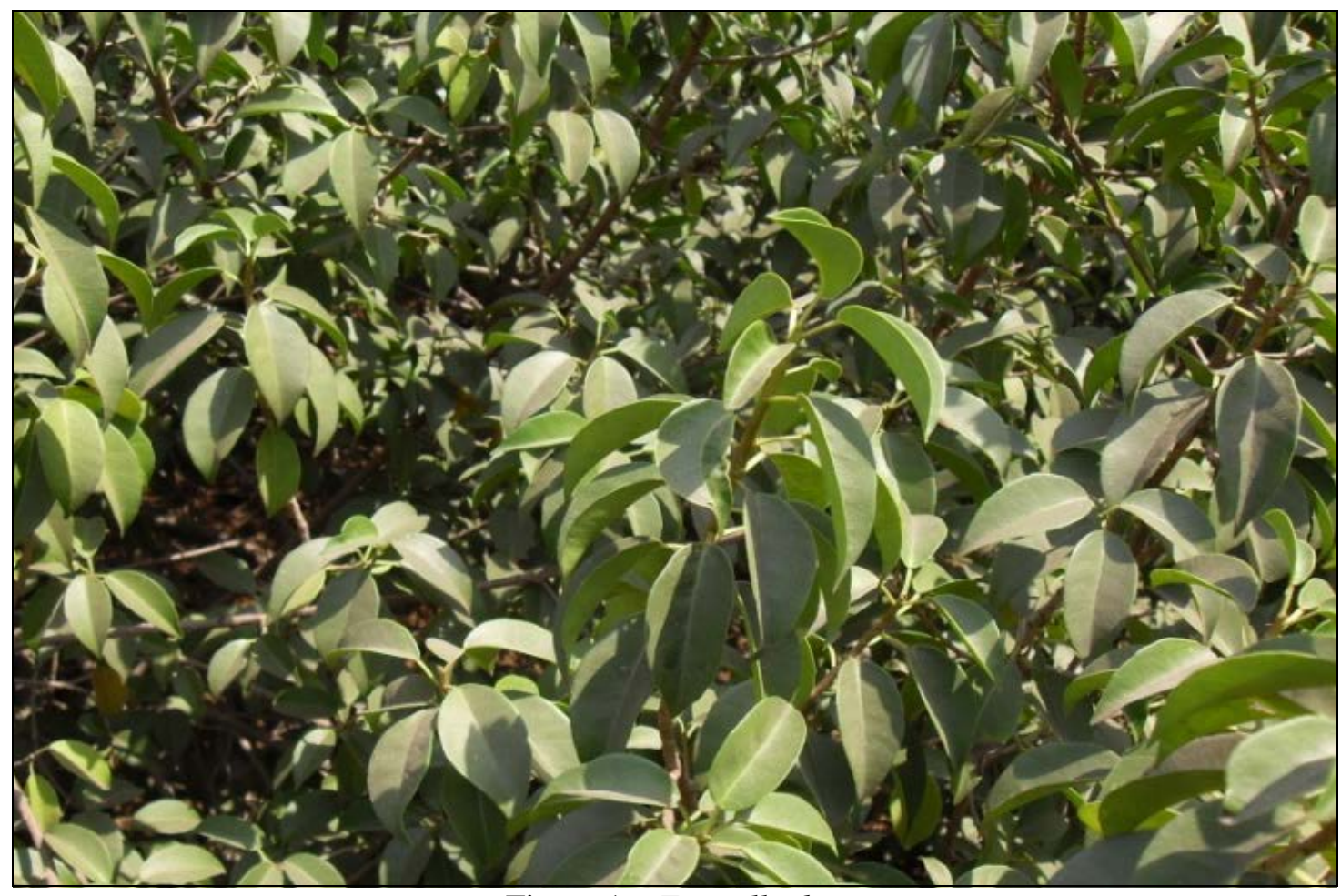

Figure 1a: E. agallocha. 


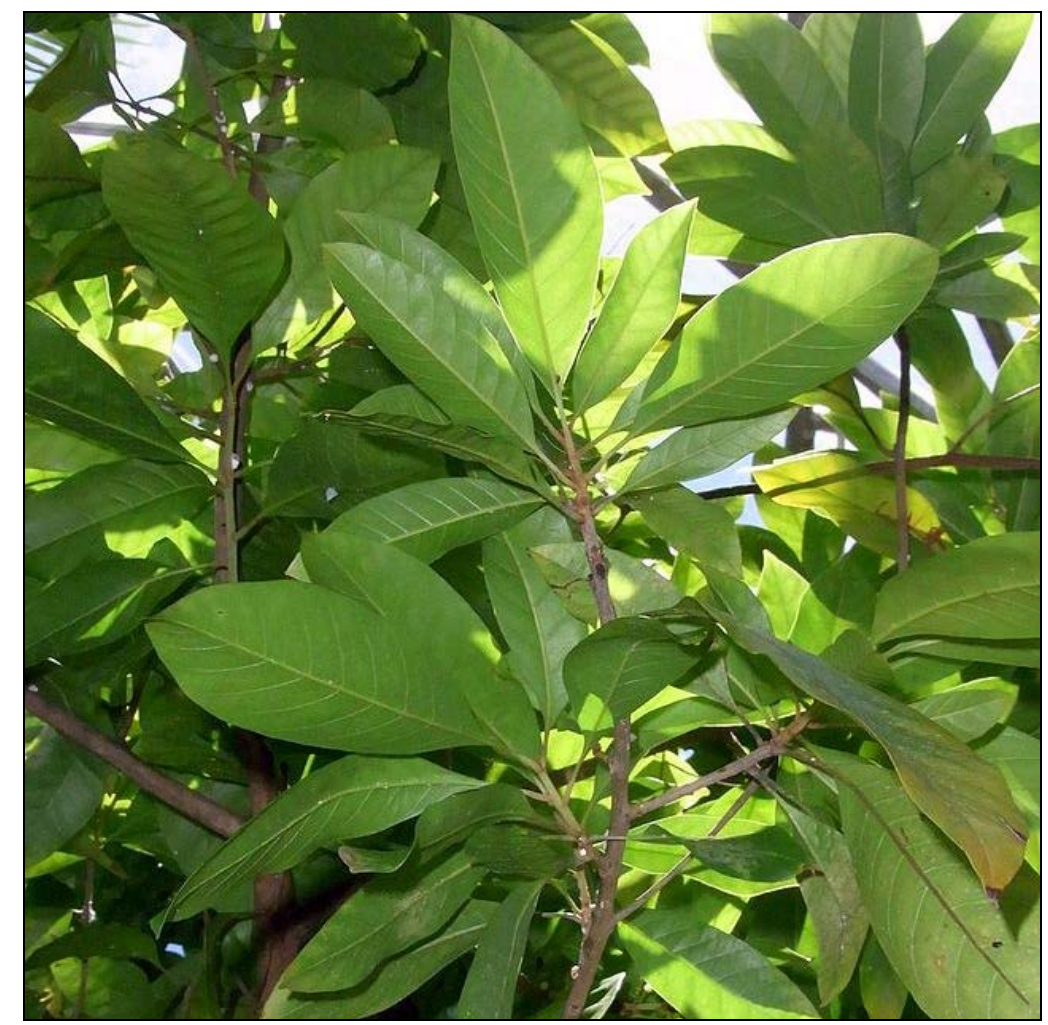

Figure 1b: Excecaria dallachyana.

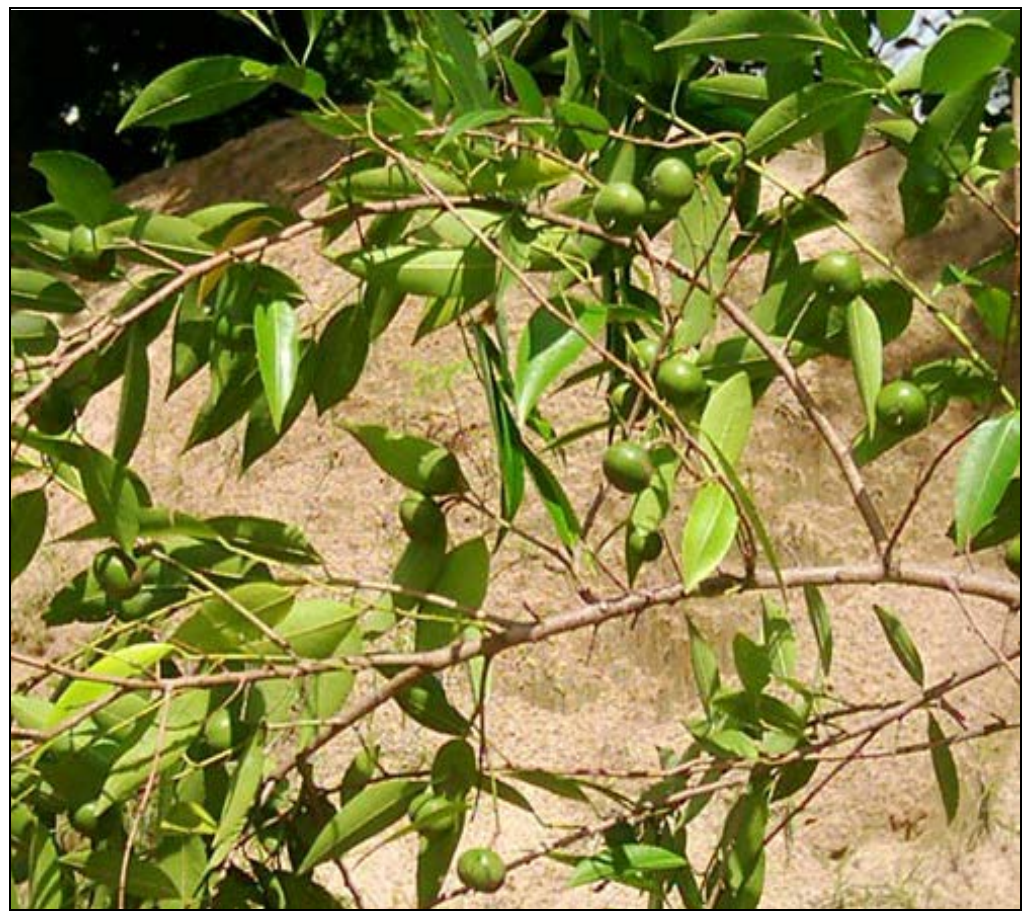

Figure 1c: Excoecaria indica. 


\section{MATERIAL AND METHODS}

Excoecaria agallocha distributed in the Godavari mangrove wetland in the State of Andhra Pradesh, India was used for the study during 2014-2015. It is a common mangrove associate and grows naturally from oligo to poly-haline areas within the mangrove forest. It is common towards land side, but extends and expands its occurrence as a weed in cut or open areas throughout the mangrove forest. Since the plant is dioecious, surveys were made to calculate the ratio of male and female trees growing in this area. Floral structural and functional aspects such as anthesis, anther dehiscence, flowering phenology, flower morphology, pollen production, pollen-ovule ratio, nectar production, stigma receptivity, breeding system, natural fruit set, seed set, foraging activity of insects, and pollen carrying rate were investigated in detail as per the protocols provided in Dafni et al. (2005). Further, anemophily occurrence and seed dispersal strategies were examined in the field itself.

\section{RESULTS}

Phenology. Phenology. It is a semi-deciduous tree with spreading branches (Fig. 1a). Young twigs and mature trunk base present lenticels. The aerial parts leak out white latex when wounded. Individual trees bear either male or female flowers but not both. Male and female trees occur in the ratio of 2:1 and both flower simultaneously during June-August. In male trees, the inflorescence is pendulous catkin and born in axillary position (Figs. 1b-d) while in female trees, the inflorescence represents an erect mixed cyme which is also borne in axillary position. In male trees, the inflorescences produce a mean number of 195 flowers over a period of five or six days. In female trees, the inflorescences produce an average of 12 flowers over a period of four or five days.

The Flower. Male flowers are bracteate, sessile, odourless, very small, and zygomorphic. Sepals are three, light green, valvate and persistent (Fig. 1e). Stamens are three, free, small, fertile; filament is light yellow, $10 \mathrm{~mm}$ long and glabrous, anther bi-locular, basifixed to almost versatile, extrorse, round, yellow, one mm long (Fig. 1f). Pistillode is absent.

Female flowers are bracteate, bracts glandular, sessile, odourless, ovoid and zygomorphic. Sepals are three, glabrous, green, valvate and wider than those in male flowers. Staminodes are absent. Ovary is syncarpous, superior with three carpels and three locules; each locule consists of a single basal ovule. The ovary consists of three short, spreading and recurved simple two mm long styles.

Floral biology. The male and female mature buds open at 06.00-09.00 hrs and anthesis in the inflorescences of both the sexes is acropetal. In male flowers, sepals unfold gradually in a time span of about 30 minutes. Then, stamens are exposed and anthers are quite prominent to the naked eye. Another dehiscence occurs about 30 minutes after anthesis by longitudinal slits. The pollen output per anther is 2,201 \pm 205.4 (Range 1,938-2,572) and per flower is 6,603 pollen grains. Pollen grains are powdery, ptychotreme, tricolporate, dark yellow, exine thick, and $33.2 \mu \mathrm{m}$ in size. The pollen-ovule ratio is 35,259.4:1. The pollen protein content per anther is three $\mu \mathrm{g}$ and per flower is nine $\mu \mathrm{g}$. Nectar is present in traces only. Flowered male inflorescences hang downwards and gradually wither away.

In female flowers, sepals, being inconspicuous, do not enclose the ovary and styles. The closely spaced erect styles reflex downward exposing their upper surface; this position was considered as the period of anthesis and commencement of receptivity to pollen grains. Further, the period of receptivity was confirmed by hydrogen peroxide test. The receptivity remains until the afternoon of the 2nd day and the styles remain in place even after fruit maturation. A female flower produces $0.81 \pm 0.2$ (Range $0.5-1.2$ ) $\mu \mathrm{l}$ of nectar. 


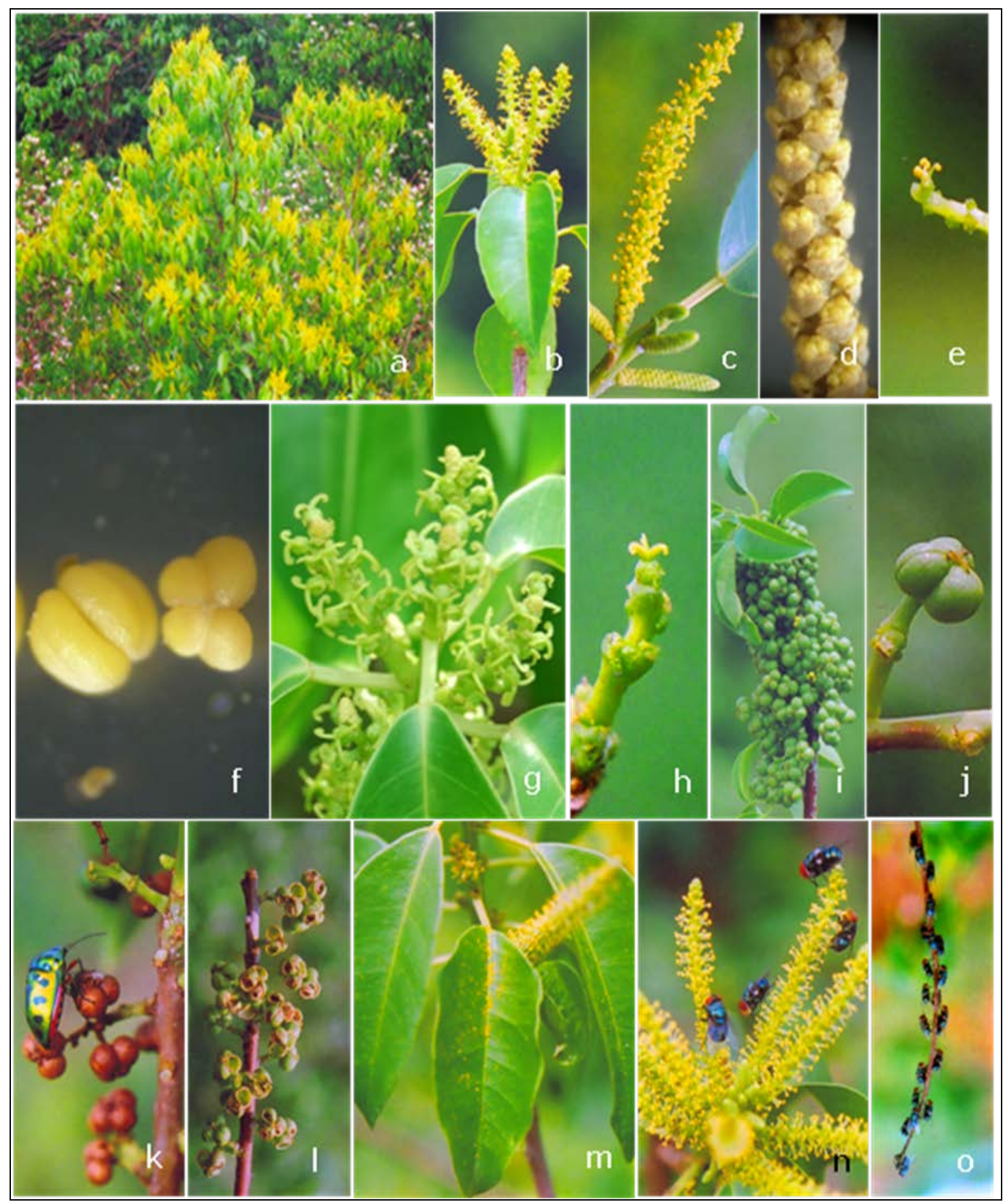

Figure 1: Excoecaria agallocha: a. Habitat; b. Male catkin; c. Flowering male catkin; d. Young male catkin; e. Male flower; f. Anthers; g. Female catkin; h. Female flower; i. Fruit set in open pollinations; j. Single fruit; k. Chrysocoris patricius feeding on mature fruits; l. C. patriciusdamaged fruits; $\mathrm{m}$. Wind-driven pollen fall on leaves; n. Chrysomya megacephala collecting forage from male flowers; o. C. megacephala sucking sap from the stem. 
Breeding systems. As male and female trees are different, the sexual system represents dioecy. Pollen flow from male to female trees occurs only with the assistance of external agents which include wind and insects. Pollen release from male trees due to the action of wind was observed as shown in figure $1 \mathrm{~m}$.

Pollination mechanism and Pollinators. Male flowers were foraged during daytime from $06.00-17.00$ hrs by different insects. The insects recorded on male catkins were bees (Apis dorsata - figure 2b, A. cerana, A. florea - figure 2d, Nomia sp. - figure 2e, Xylocopa sp., $X$. pubescens and $X$. latipes), flies (Chrysomya megacephala - figure $1 \mathrm{n}$ and Eristalinus arvorum - figure 2a) and butterflies (Acraea violae - plate 21i, Danaus chrysippus - figure 2f, D. genutia, Hypolimnas bolina - figure $2 \mathrm{j}$, Junonia almana - figure $2 \mathrm{~g}$, J. lemonias - figure 2h, Tirumala limniace - figure 2k, and Cynthia cardui - figure 2l) (Figs. 3-5). All the bee species were found to collect pollen and nectar while flies and butterflies gathered nectar only. While collecting pollen and/or nectar, bees and flies got dusted with pollen on their ventral side. In case of butterflies, while collecting nectar, their proboscis, head, and abdomen touched the anthers, and in the process, these parts were coated with pollen. Body washings of these insects revealed the presence of pollen grains. The average number of pollen grains is 333.91,107.5 for bees, 98-398 for flies, and 36.2-100 for butterflies (Tab. 1). The hourly foraging activity of each category of insects was found to vary with the time of day. Bees and flies consistently collected the forage with varying numbers of visits at each hour, while butterflies confined their nectar collection to 07.00-12.00 hrs with varying numbers of visits at each hour during this period. Of the total number of foraging visits, A. dorsata made $27 \%$ and $C$. megacephala $26.3 \%$ of visits while other species, each made visits ranging from 0.8 to $8.2 \%$ (Fig. 6).

The female flowers were foraged by insects during 06.00-14.00 hrs (Fig. 7). The insects recorded on female trees included the same insect species which were found on male trees; the bees A. cerana, Xylocopa species and butterflies, Tirumala limniace and Cynthia cardui however, were not found. All these insect species collected nectar only as the flowers are devoid of stamens. A. dorsata (Fig. 2c) and butterflies began foraging activity from $06.00 \mathrm{~h}$ while all other insects from $07.00 \mathrm{~h}$, and all ceased their nectar collection by 12.00/13.00 hrs. These insect species, individually, made 7.5 to $12 \%$ of foraging visits (Fig. 8). While collecting nectar, the underside of their body invariably contacted the styles and the pollen carried by them was transferred to the upper surface of the styles. The pollen deposition rate was more at 09.00-10.00 hrs (Fig. 9). The styles in virgin female flowers when exposed by removing bags during 14.00-17.00 hrs were found with pollen grains; the number ranged from 25-57. The deposition of pollen grains during this period was considered to be a result of pollen transfer by wind action. C. megacephala also feeds on the sap of stems of both male and female trees (Fig. 10). 


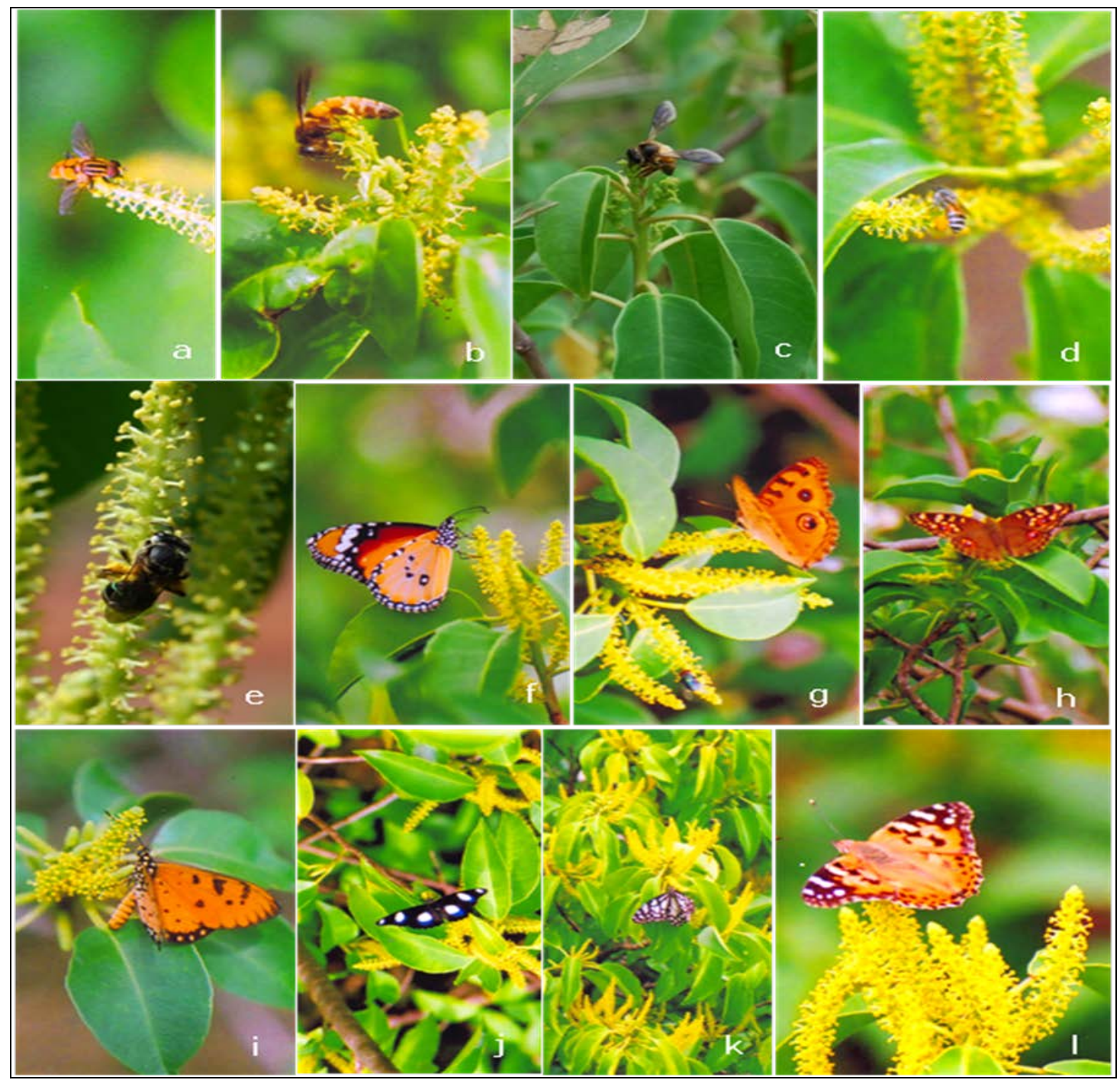

Figure 2: Excoecaria agallocha - Flower visitors a, b, d-l on male catkins and c on female catkin: a. Eristalinus arvorum; b. and c. Apis dorsata; d. Apis florea; e. Nomia sp.; f. Danaus chrysippus; g. Junonia almana; h. Junonia lemonias; i. Acraea violae; j. Hypolimnas bolina; $k$. Tirumala limniace; l. Cynthia cardui.

Fruiting ecology. Fruit set is 92\% in open-pollinations (Fig. 1i). A beetle species, Chrysocoris patricius voraciously fed on fruits and its percent stood at 25\% (Figs. 1k, l). Fruits mature within 40 days. Individual fruits produce 3 seeds (Fig. 1j); they are leathery, 3-lobed with green to dark brown pericarp through maturation. Fruits dehisce explosively and disperse seeds. The seeds float in tidal water and eventually anchor in a suitable soil environment. The seeds fall to the ground and anchor in the soil within the parental sites if the soil is exposed at the time of fruit dehiscence. Table 2 presents sequential events of sexual reproduction in this plant. 


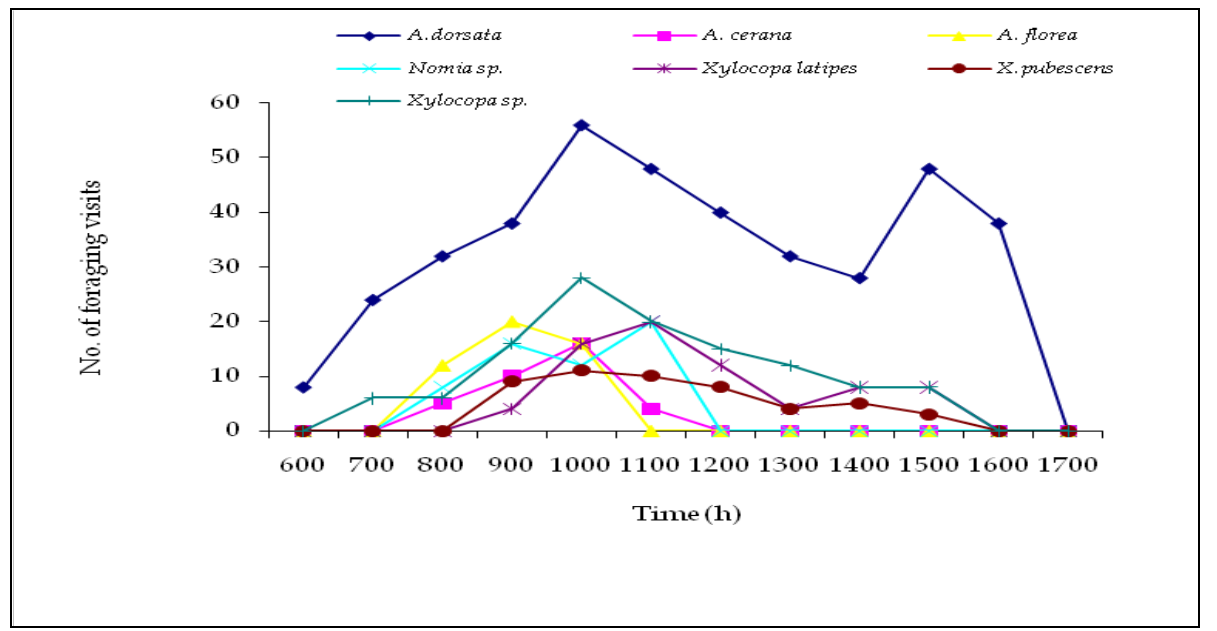

Figure 3: Hourly foraging activity of bees on male trees of Excoecaria agallocha.

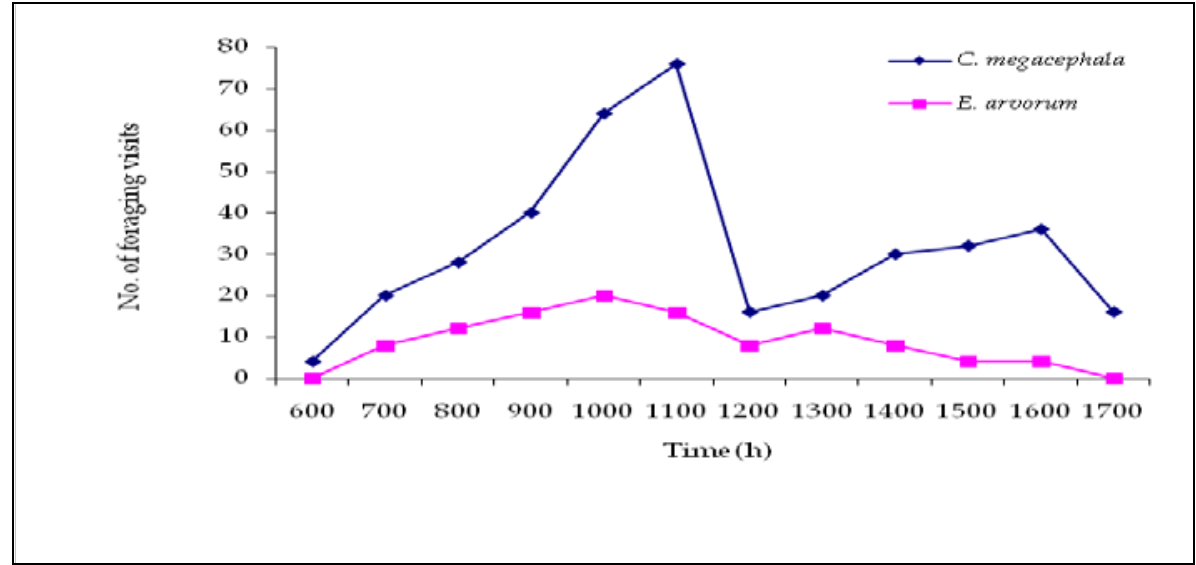

Figure 4: Hourly foraging activity of flies on male trees of Excoecaria agallocha.

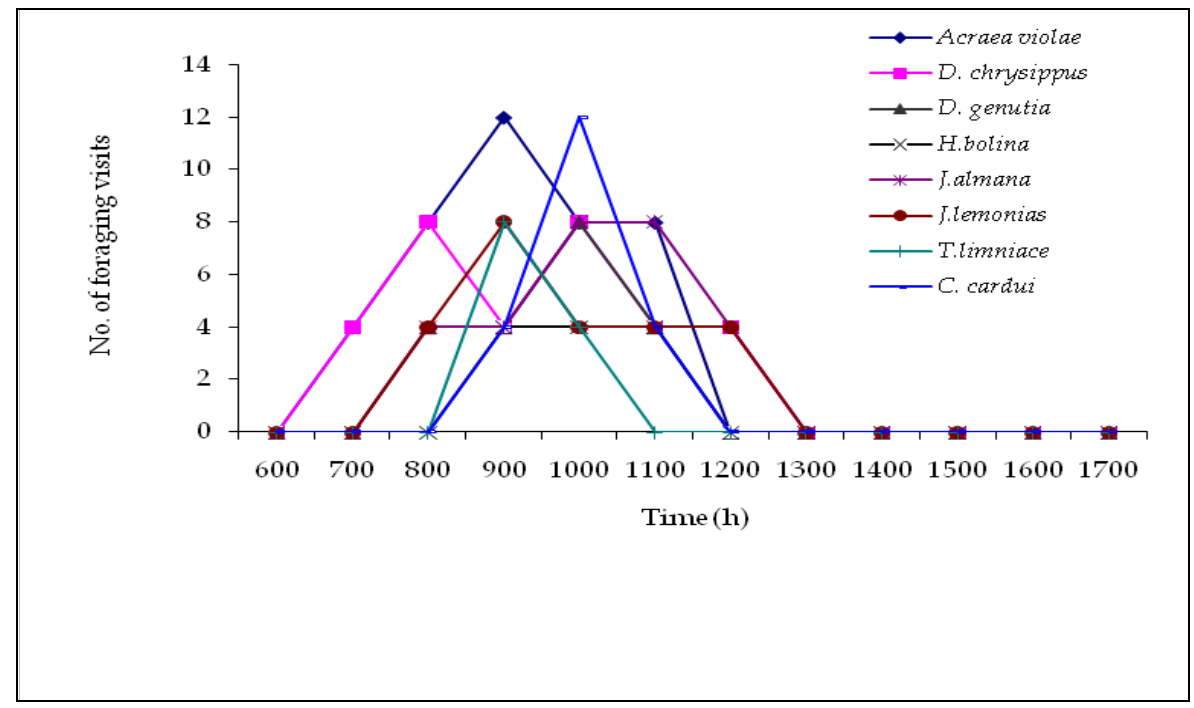

Figure 5: Hourly foraging activity of butterflies on male trees of Excoecaria agallocha. 


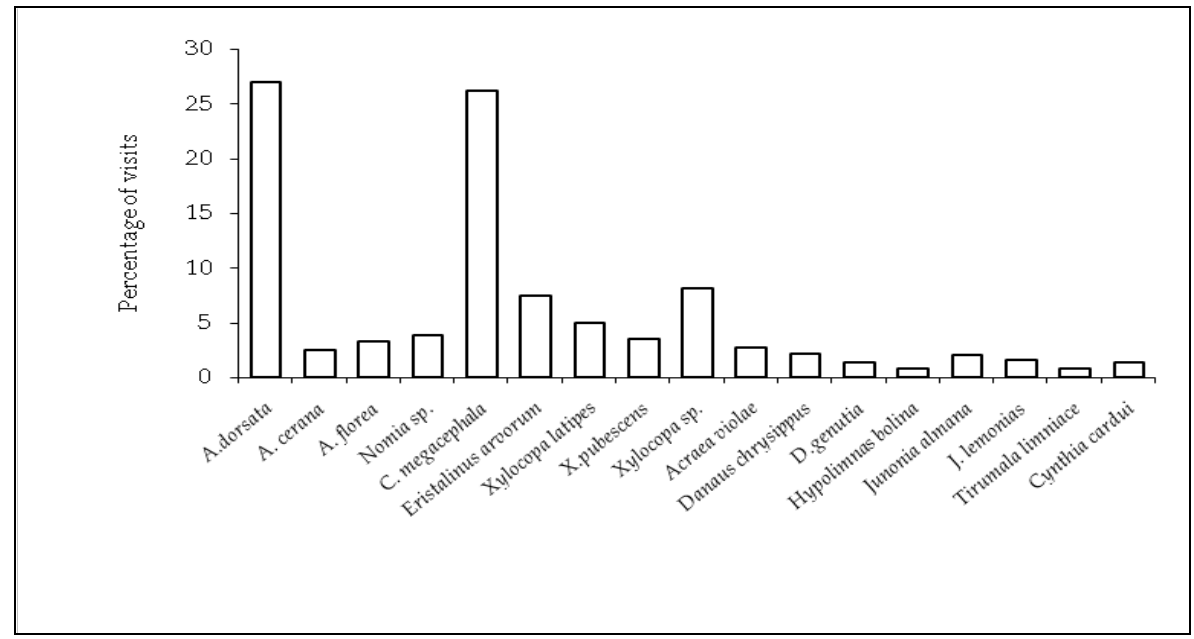

Figure 6: Percentage of foraging visits of insects on male trees of Excoecaria agallocha.

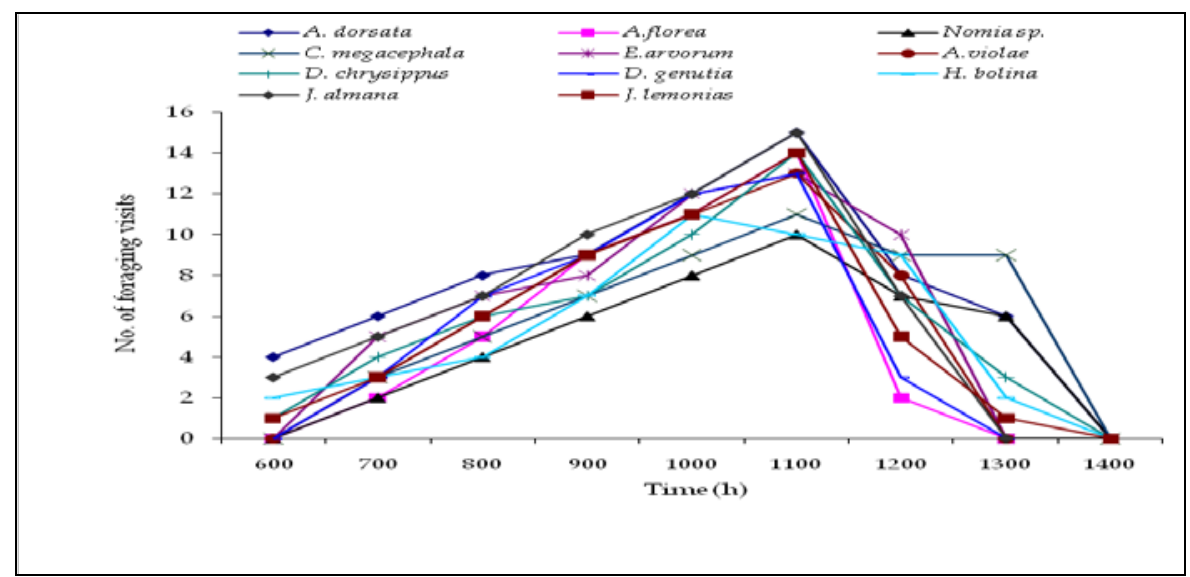

Figure 7: Hourly foraging activity of insects on female trees of Excoecaria agallocha.

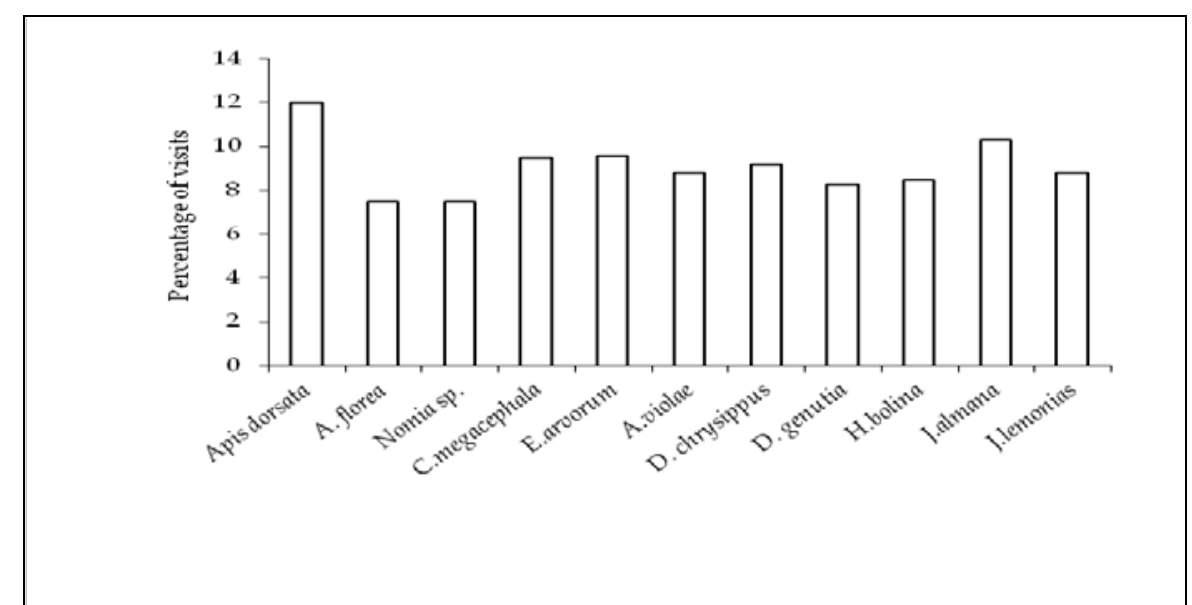

Figure 8: Percentage of foraging visits of insects on female trees of Excoecaria agallocha. 


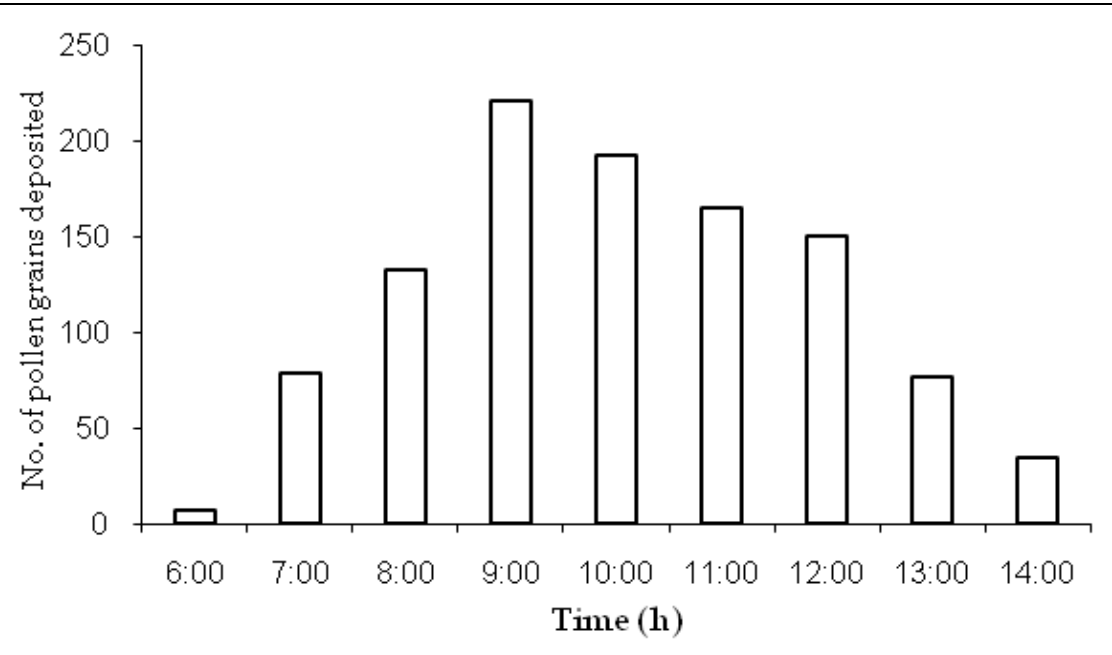

Figure 9: Pollen deposition rate on the styles of Excoecaria agallocha. agallocha.

Table 1: Pollen carrying capacity of insect foragers on male trees of Excoecaria

\begin{tabular}{|l|c|c|c|}
\hline Insect species & Sample size & Range & Mean \pm S.D. \\
\hline Apis dorsata & 10 & $321-762$ & $550.7 \pm 155.62$ \\
\hline A. cerana & 10 & $215-423$ & $392.7 \pm 91.97$ \\
\hline A. florea & 10 & $240-423$ & $333.9 \pm 61.60$ \\
\hline Nomia sp. & 10 & $276-578$ & $423.4 \pm 114.38$ \\
\hline Chrysomya megacephala & 10 & $78-123$ & $98 \pm 10.5$ \\
\hline Eristalinus arvorum & 10 & $76-97$ & $398 \pm 64.06$ \\
\hline Xylocopa latipes & 10 & $819-1379$ & $1107.5 \pm 194.36$ \\
\hline X. pubescens & 10 & $912-1259$ & $1030.7 \pm 115.62$ \\
\hline Xylocopa sp. & 10 & $765-1074$ & $898 \pm 101.92$ \\
\hline Acraea violae & 10 & $54-68$ & $61 \pm 8.5$ \\
\hline Danaus chrysippus & 10 & $24-86$ & $54 \pm 9.5$ \\
\hline D. genutia & 10 & $43-67$ & $50 \pm 11.3$ \\
\hline Hypolimnas bolina & 10 & $76-121$ & $98.4 \pm 14.3$ \\
\hline Junonia almana & 10 & $85-116$ & $100 \pm 5.7$ \\
\hline J. lemonias & 10 & $23-54$ & $36.2 \pm 12.4$ \\
\hline Tirumala limniace & 10 & $43-65$ & $53.3 \pm 15.4$ \\
\hline Cynthia cardui & 10 & $45-67$ & $56.2 \pm 9.5$ \\
\hline
\end{tabular}


Table 2: Chronological events of sexual reproduction in Excoecaria agallocha.

\begin{tabular}{|l|l|}
\hline Floral event & Excoecaria agallocha \\
\hline Anthesis & $06.00-09.00$ hrs \\
\hline Anther dehiscence & 30 minutes after anthesis \\
\hline Sepals & Sepals are persistent \\
\hline Petals & Absent \\
\hline Stamens & $\begin{array}{l}\text { Empty anthers and filaments remain in place for a long } \\
\text { time }\end{array}$ \\
\hline Style (s) & Persistent \\
\hline Stigma & Absent \\
\hline Stigma receptivity & $\begin{array}{l}\text { Styles receptive to pollen from anthesis to afternoon of } \\
\text { 2nd day }\end{array}$ \\
\hline Pollen output/flower & 6,603 \\
\hline Pollen protein/flower $(\mu \mathrm{g} / \mathrm{mg})$ & nine $\mu \mathrm{g}$ \\
\hline Pollen-ovule ratio & $35,259.4: 1$ \\
\hline Nectar volume/flower ( $\mu \mathrm{l})$ & $\begin{array}{l}\text { Male flowers - traces } \\
\text { Female flowers -0.8 } \pm 0.2\end{array}$ \\
\hline Pollination mechanism & Unspecialized \\
\hline Pollinators & Bees, flies and butterflies \\
\hline Breeding system & Cross \\
\hline Bud abortion (\%) & Nil \\
\hline Fruit abortion (\%) & Nil \\
\hline Fruit set in open pollinations $(\%)$ & $92 \%$ - Fruit predation: $25 \%$ \\
\hline Fruit maturation time (days) & $35-40$ \\
\hline Fruit orientation & Erect \\
\hline Seed output/fruit & three \\
\hline Planting strategy & Self-planting and stranding \\
\hline &
\end{tabular}

\section{DISCUSSION}

Excoecaria agallocha grows from oligohaline to polyhaline zones in the mangrove forest. It is dioecious and flowers for about three months during the rainy season. The flowering is synchronous in both male and female trees. In the sampled sites, the ratio of male to female trees is 2.2:1, and the ratio of male to female flowers at inflorescence level is $16: 1$. Male flowers produce rich amount of protein-poor pollen while three-ovuled ovary is the characteristic of female flowers. Both the male and female flowers are small and lacking odour. The anthers in male flowers are free, exposed and versatile; the conditions of which facilitate the release of pollen into the air. Collectively, all of these characteristics suggest that the plant is adapted for anemophily, also, the pollen is released into the air due to wind action. However, there is also a lot of wastage of pollen during its travel from male to female flowers. In this context, wind-pollination is not economical, not reliable as pollen vector, and is energetically expensive for the plant. 
In E. agallocha, the long catkins of male trees and the short mixed cymes of female trees display a number of flowers. The presence of several such inflorescences on each tree simultaneously is quite attractive to foragers. The yellow stamens and bright green shining styles may further enhance attractiveness to foragers. Both the flower sexes produce nectar; it is trace in male flowers while it is relatively measurable in female flowers. These characteristics indicate that the plant evolved for pollination by insects. The study also indicated that bees, flies, and butterflies visit both male and female flowers during daytime and pollinate the styles in female flowers. Body washings of these insects also indicated that they are pollen carriers and transfer pollen to styles of female flowers. The styles show receptivity also on the 2nd day, the characteristic of which facilitates pollination in case of failure of pollination on the day of anthesis. Therefore, the flower morphology and functional characteristics suggest that the plant is evolved for pollination by both wind and insects. In support of this, Tomlinson (1986) reveals that the plant may be bee-pollinated. The ability of the plant to utilize abiotic and biotic agents for fruit set is highly adaptive for the successful colonization of mangrove areas. Field observations also indicate that it is an invasive species and colonizes easily in cut or naked areas of mangroves by disallowing the growth and development of established seedlings of true viviparous and crypto-viviparous species.

Rao et al. (1998) reported that in E. agallocha, the dioecious nature, the predominance of male trees over female trees, and its poor seed set and germination restrict its multiplication through sexual reproduction. On the contrary, the present study shows that this plant depicts more than $90 \%$ of fruit set and each fruit characteristically produces three seeds. But, fruit predation by a green beetle, Chrysocoris patricius, to an extent of $25 \%$ has been found to be responsible for reducing the success rate of sexual reproduction. Seeds lack dormancy and release explosively from the mature fruit capsules (Das and Ghose, 2003). The released seeds settle and produce new plants within the parental sites if the latter are exposed and, if not, seeds float in tidal water due to the presence of an air space within the seed coat and establish in different salinity zones of mangroves.

\section{CONCLUSIONS}

Excoecaria agallocha is the only dioecious species in the mangrove forest. It is a highly successful mangrove associate due to its ability to occupy different salinity zones within the mangrove forest. It bears fruits through entomophily and anemophily and disperse seeds by self-planting and stranding strategies. With these abilities, it is able to invade the cleared or open areas and dominate the mangrove flora. A green beetle, Chrysocoris patricius is its natural control since it significantly reduced fruit set rate by fruit predation. 


\section{ACKNOWLEDGEMENTS}

We thank the Andhra University, Visakhapatnam, for providing facilities to carry out the work presented in the paper. We also thank Venkata Ramana K., Department of Environmental Sciences, Andhra University, Visakhapatnam, for providing assistance during field work in Coringa Mangrove Forest. 


\section{REFERENCES}

1. Alang R. N. N. R., Jusoh W. F. A. W., Nur-Zati A. M. and Hashim N. R. 2010 - Ant diversity on Sonneratia caseolaris trees in Rembau-Linggi mangrove forest, Peninsular Malaysia, Transylvanian Review of Systematical and Ecological Research, 10, The Wetlands Diversity, 7782.

2. Azis T. N. A. and Hashim N. R., 2010 - Heavy metal concentrations in an important mangrove palm (Nypa fruticans), in Rembau-Linggi Mangrove Forest (Peninsular Malaysia), Transylvanian Review of Systematical and Ecological Research, 12, The Wetlands Diversity, 111-116.

3. Bandaranayake W. M., 1998 - Traditional and medicinal uses of mangroves, Mangroves and Salt Marshes, 2, 133-148.

4. Blasco F., Aizpuru M. and Gers C., 2001 - Depletion of the mangroves of Continental Asia, Wetlands Ecology and Management, 9, 245-256.

5. Dafni A., Kevan P. G. and Husband B. C., 2005 - Practical Pollination Biology, Enviroquest Ltd., Ontario, 590.

6. Das S. and Ghose M. 2003 - Seed structure and germination pattern of some Indian mangroves with taxonomic relevance, Taiwania, 48, 287-298.

7. Das S. and Siddiqui N. A. 1985 - The mangroves and mangrove forests of Bangladesh, UNDP/FAO Project BGD/79/017, Rome.

8. Field C. D., 1998 - Rehabilitation of mangrove ecosystems: an overview, Marine Pollution Bulletin, 37, 383-392, doi:10.1016/s0025-326x(99)00106-x

9. $\quad$ Miles D. H., Kokpol U., Chittawong V., Tip-Pyang S., Tunsuwan K. and Nguyen C., 1998 Mangrove forests - The importance of conservation as a bioresource for ecosystem diversity and utilization as a source of chemical constituents with potential medicinal and agricultural value, Pure and Applied Chemistry, 70, 1-9.

10. Rao C. S., Eganathan P., Anand A., Balakrishna P. and Reddy T. P., 1998 - Protocol for in-vitro propagation of Excoecaria agallocha L., a medicinally important mangrove species, Plant Cell Reports, 17, 861-865.

11. Spalding M. D., 1997 - The global distribution and status of mangrove ecosystems', Mangrove Edition, International Newsletter of Coastal Management (Intercoast Network) Special Edition \#1. Narragansett: Coastal Resources Center, University of Rhode Island, 20-21.

12. Tomlinson P. B., 1986 - The Botany of Mangroves, Cambridge University Press, New York, 413.

13. Zhengyun Z., Zhixian S., Qiaoying Z. and Aiying S., 2003 - The current status of world protection for mangrove forest, Chinese Journal of Oceanology and Limnology, 21, 261-269. 